\title{
Internationalisation of Construction Business and E-commerce: Innovation, Integration and Dynamic Capabilities
}

\author{
Thayaparan Gajendran, (The University of Newcastle, Australia) \\ Graham Brewer, (The University of Newcastle, Australia) \\ Malliga Marimuthu, (Universiti Sains Malaysia, Malaysia)
}

\begin{abstract}
The role of internet and web based applications in delivering competitive advantage through ebusiness process is widely acknowledged. However, little is done by way of research to use the dynamic capability framework to explore the role of ecommerce in the construction business internationalisation. The aim of this paper is to present a literature based theoretical exploration using dynamic capability view to discuss internationalising construction businesses through electronic commerce (e-commerce) platforms. This paper contextualises the opportunities for internationalising construction, using a mix of supply chain paradigms, embedded with ecommerce platforms. The discussion concludes by identifying the potential of dynamic capabilities of a firm to exploit the innovation and integration potential of different e-business systems, in contributing to the internationalisation of construction businesses. It proposes that contracting firms with developed dynamic capabilities, has the potential to exploit e-commerce platforms to channel upstream activities to an international destination, and also offers the firm's products and services to international markets.
\end{abstract}

Keywords: Dynamic Capabilities, Innovation, E-commerce, Building Information Modelling (BIM), Integration, Internationalisation

\section{Introduction}

International business is characterised by any form of transaction taking place across national borders for the purpose of satisfying the needs and demands of individuals and firms (Rugman and Collinson 2009). The opportunities arising from globalisation, while elevating competition in domestic markets, provide construction firms with access to international markets. A number of construction firms already operate in international markets, trading their design services (Reina and Tulacz, 2010a) and construction products or servicesii (Reina and Tulacz, 2010b), amounting to significant monetary value. Internationalising a construction business is a complex process involving decisions on what international region, country or market to enter; how to make the international market entry (as exports-imports or foreign direct investments) and what is the best-fit business model(s) for gaining sustained competitive advantage (See Rugman and Collinson, 2009; Howes and Tah 2003; London, 2010).

Construction firms (e.g. contracting and consulting firms including architectural and project management firms) could exploit international markets in at least two forms: (a) outsource their selected core or non-core business functions or operations to an international operator (supplier focus) and/or (b) offer the firm's products or services in the international market (customer focus). Firms can choose to internationalise their business via an import or export mode or foreign direct investment mode (FDI) (Menipaz and Menipaz 2011). Construction firms may view their core business as being dominated by knowledge or design (e.g. architect, specialist design, project management, management contracting services etc.), manufacturing or 
production (e.g. building components production: lifts, escalators etc.), assembly (e.g. fabricators, principal contractors, labour sub-contracting services etc.) or a hybrid of some, or all, of the above.

Construction firms, in internationalising their business, need to be innovative and fully understand their capabilities, specifically their 'dynamic capabilities' (Teece, 2007), which enable them to sustain competitive advantage. Dynamic capability is defined as those capabilities that "operate to extend, modify or create ordinary capabilities to give competitive advantage" (Winter, 2003: 991). The ability of appropriate resources and capabilities (Teece, Pisano and Shuen, 1997; Daniel and Wilson 2003) for the skilful design and execution of an ebusiness model (Wu and Hisa, 2008) contextualised through the supply chain, can offer firms the desired competitive edge (Ash and Burn, 2003; Smart, 2008; Roy, Sivakumar and Wilkinson, 2004).

Lambert and Cooper (2000: 65) indicates that "one of the most significant paradigm shifts of modern business management is that individual businesses no longer compete as solely autonomous entities, but rather as supply chains". Supply chains are primarily focused on how the firm delivers its products and services to clients via effective flow of material, plant, people, finances and information. Therefore, the need to conceptualise the design and operations of a business from a supply chain perspective, has gradually gained significant attention (Min \& Zhou, 2002; Cutting-Decelle et al., 2007; Vrijhoef and Koskela, 2000). The evolution of supply chain paradigms is coupled with developments in the Information and Communication Technologies (ICT) and vice versa (Pant, Sethia, and Bhandarib, 2003; Donk, 2008). Historically ICT developments in the organisations moved from the 'automation agenda' to 'inter firm integration' and then to 'supply chain wide integration' (Show, 2000; Fawcett, and Magnan, 2002; Fawcett et al., 2007) while the supply chain integration agenda focused on exploiting ICT/e-commerce developments for improved communication, customer relationship management, demand management, production management etc. (Donk, 2008). The mutual aim of both e-business and supply chain management, are about performing effective business transactions between the trading partners through sharing of business information and developing or maintaining good business relationships (Zwas,s 1996; Min \& Zhou, 2002). Therefore, blending the alternative e-commerce models with supply chain paradigms (see Smart 2008) is critical in unearthing and exploiting the dynamic capabilities of a firm (Ash and Burn, 2003) and these efforts have been emphasised for global supply chain by Eyob and Tetteh (2012).

This paper explores the possible dynamic capabilities that construction firms can marshal through developing alternative e-business models, contextualised through the supply chain perspectives, to internationalise their business. In doing so, this paper also evaluates the issues that are beyond the control of the firms, impacting internationalisation using ecommerce platforms.

\section{Dynamic Capabilities: a Synopsis}

Teece (2007) suggests that firms operating in globally competitive environments with geographically dispersed operations require more than the ownership of difficult-to-replicate assets to attain sustainable advantage. He suggests that such firms 'also require unique and difficult-to-replicate dynamic capabilities'. Teece and Pisano (1994) term dynamic as:

the shifting character of the environment; certain strategic responses are required when time-to-market and timing is critical, the pace of innovation accelerating and the nature of future competition and markets difficult to determine. The term capabilities emphasises

Gajendran, T et al. (2013) 'Internationalisation of construction business and e-commerce: Innovation, integration and dynamic capabilities', Australasian Journal of Construction Economics and Building, 13 (2) 1-17 
the key role of strategic management in appropriately adapting, integrating and reconfiguring internal and external organisational skills, resources and functional competencies toward the changing environment. ( $p 1)$

Dynamic capabilities are about a firm's ability to deploy resources or capabilities in effective combinations and modify its specific organisational processes to achieve its goals where the resources and capabilities can be tangible and intangible (see also Makadok 2001). The nature of the dynamic capabilities is well explained as an extension of resource based view (RBV) that describes the conditions under which firms, based on their bundles of resources and capabilities may achieve a sustained competitive advantage (Barreto, 2010). Eisenhardt \& Martin (2000) describes dynamic capabilities as:

The firm's processes that use resources - specifically the processes to integrate, reconfigure, gain and release resources - to match and even create market change. Dynamic capabilities are therefore the organisational and strategic routines by which firms achieve new resource configurations as markets emerge, collide, split, evolve and die. (p.1107)

Ambrosini and Bowman (2009: 31) suggest Teece, Pisano and Shuen (1997) and Nelson and Winter (1982) "take an efficiency approach to firm performance rather than a privileged market position approach (the latter being the underpinning for Porter's (1980) theory of competitive advantage)". Porter's (1990) Competitive Advantage Theory proposes that any firm that understands and manages the effects of the five major factors, namely: demand conditions, presence or absence of supporting suppliers, degree of rivalry, threat of new entrants and threat of substitutes, will posses significant competitive advantage over competitors. The proponents of the dynamic capability approach places emphasis on the internal factors of the firm (rather than external factors) contributing to competitive advantage (Ambrosini and Bowman, 2009).

Teece's (2007) conceptualisation of dynamic capabilities comprises three distinct processes (or routines), namely sensing, seizing and reconfiguring the resource base. Sensing opportunities (and threats) is about scanning the environment (e.g. markets, technological advancements etc) to identify new opportunities (Teece, 2007). 'Sensing' requires construction firms to maintain good relationships with trading partners, (for example, suppliers, contractors etc) and to spot related advancements that can create new opportunities. 'Seizing' opportunities is about capturing existing and emerging opportunities, and possible investments in relevant technologies (O'Reilly III and Tushman, 2008; Teece, 2007). 'Reconfiguring' the resource base is about a firm's ability to recombine its internal and external resources and operating capabilities (Teece, 2007) to create sustained competitive advantage.

The dynamic capabilities framework provides a sensible approach to analyse the e-commerce initiatives in internationalising the construction business. Daniel and Wilson (2003) argue that dynamic capabilities are critical for businesses operating through e-business models to provide them with sustained competitive advantage. They argue that two groups of capabilities are essential for e-business adoption: the first group is associated with the sensing and seizing (routines) to identify innovative approaches to design of e-business environments, while the second group relates to reconfiguring and integrating resources associated with e-business initiatives within the existing operations of the business. It is argued that both groups of capabilities can best be analysed via the supply chain context as it provides a holistic perspective to connectivity between trading partners in construction projects. Daniel and Wilson (2003) identified eight innovation and integrative capabilities mostly encapsulating the three dynamic capacity routines. Below, the dynamic capabilities (sensing, seizing and re configuring)

Gajendran, T et al. (2013) 'Internationalisation of construction business and e-commerce: Innovation, integration and dynamic capabilities', Australasian Journal of Construction Economics and Building, 13 (2) 1-17 
proposed by Teece (2007) are explored through innovative and integrative capabilities proposed by Daniel and Wilson (2003) in the context of e-business transformation (see also Wu and Hisa 2008; Rindova and Kotha, 2001).

1. Innovation in culture and climate: ability of a firm to foster strategic changes, both intra firm and inter firm (e.g. across supply chain), through building commitment to resource reconfiguration. It is critical that the culture of a firm fosters routines of sensing, seizing and reconfiguring.

2. Innovation in harnessing competence base: the skill set in a firm to deal with uncertain information (sensing) and develop business cases (seizing) incorporating substantial alterations to their business model as to deliver effective resource reconfiguration (reconfiguring).

3. Innovation in vision and strategy: ability of firms to rapidly develop and implement corporate strategies to enable them to engage with resource adoption and reconfiguration in a speedy manner. The strategic ability of a firm to rapidly seize and reconfigure a sensed opportunity is critical for competitive positioning.

4. Innovation in organisational intelligence: ability of a firm to blend 'planned' and 'experiential' approaches for iterative development of customer value propositions enabling firms to reconfigure resources to match market requirements. The approach to organisational intelligence in a firm is key in executing the routines of sensing, seizing and reconfiguring.

5. Innovation in idea management: ability of a firm to sense new ideas, seize them and reconfigure the resources to deliver the new idea, is key for success.

6. Integration of information systems: the ability of a firm to sense, seize and reconfigure and integrate new and existing ICT systems across the firm and its supply chain, is critical for business success.

7. Integration of strategy: ability of a firm to diligently couple e-business directions with corporate strategy directions to integrate resources. This is an extension of innovation in vision and strategy (item 3 ), but specifically reconfiguring e-technologies in the context of corporate strategy.

8. Integration of supply chains: ability of a firm to align new and existing channels to offer multi-channel operations for integrated distribution channels. Specifically, this refers to reconfiguring supply chains with electronic technologies. One could argue supply chain integration and ICT integration (Item 6) are closely aligned (see Donk, 2008; Johnson and Whang, 2002)

Therefore 'dynamic capabilities should be laid at the core of strategic management processes' (Shera and Lee, 2004: 935), wherein dynamic capabilities are tangible and intangible capabilities using resources effectively to deliver products and services. In essence, contextualising Teece's (2007) dynamic capability routines of sensing, seizing and reconfiguring through Daniel and Wilson's (2003) eight innovation and integrative capabilities, informs the potential of dynamic capabilities in the adoption of e-technologies.

\section{Innovation and Integration in Supply Chains contextualised through Dynamic Capabilities}

London (2008) identified that managing supply chains is about making improvements, particularly in: customer value, relationship management of trading partners, information management, flow of products and funds, competitiveness, innovation and reduction of costs. The supply chain context provides a lens through which to explore how trading partners are interconnected, particularly in terms of their goals, technologies, processes and relationships.

Gajendran, T et al. (2013) 'Internationalisation of construction business and e-commerce: Innovation, integration and dynamic capabilities', Australasian Journal of Construction Economics and Building, 13 (2) 1-17 
Siau and Tian (2004: 67) indicate that "the goal of supply chain integration is to link up the market place, the distribution network, the manufacturing process, and procurement activity in such a way that customers are better serviced at a lower total cost". Tan (2001: 44) suggests the goal of the integrated supply chain strategy is to create "manufacturing process and logistic functions seamlessly across the supply chain as an effective competitive weapon that cannot be easily duplicated by others", tantamount to dynamic capability. Therefore, sensing (innovation or integration) opportunities offered by e-commerce tools in the supply chain context especially global supply chain and seizing and reconfiguring resources enables firms to be agile and competitive in international markets.

\begin{tabular}{|l|l|l|}
\hline $\begin{array}{l}\text { Arcs of Integration by } \\
\text { Frohlich and Westbrook } \\
\text { (2001) }\end{array}$ & $\begin{array}{l}\text { Description of Arcs of Integration } \\
\text { by Frohlich and Westbrook } \\
\text { (2001) }\end{array}$ & $\begin{array}{l}\text { Types of Integrations by } \\
\text { Fawcett and Magnan (2002) }\end{array}$ \\
\hline (1) inward facing & $\begin{array}{l}\text { Lower quartile for suppliers and } \\
\text { lower quartile for customer }\end{array}$ & $\begin{array}{l}\text { internal, cross-functional } \\
\text { process integration }\end{array}$ \\
\hline (2) periphery facing & $\begin{array}{l}\text { Above lower quartile for suppliers } \\
\text { or customers, but below upper } \\
\text { quartile for suppliers and customers }\end{array}$ & \\
\hline (3) supplier facing & $\begin{array}{l}\text { In upper quartile for suppliers and } \\
\text { below upper quartile for customers }\end{array}$ & $\begin{array}{l}\text { backward integration with } \\
\text { valued first-tier suppliers }\end{array}$ \\
\hline (4) customer facing & $\begin{array}{l}\text { In upper quartile for customers and } \\
\text { below upper quartile for suppliers }\end{array}$ & $\begin{array}{l}\text { forward integration with valued } \\
\text { first-tier customers }\end{array}$ \\
\hline (5) outward facing & $\begin{array}{l}\text { In upper quartile for suppliers and } \\
\text { in upper quartile for customers }\end{array}$ & $\begin{array}{l}\text { complete forward and } \\
\text { backward integration }\end{array}$ \\
\hline
\end{tabular}

Table 1 Integration by Frohlich and Westbrook (2001) and Fawcett and Magnan (2002)

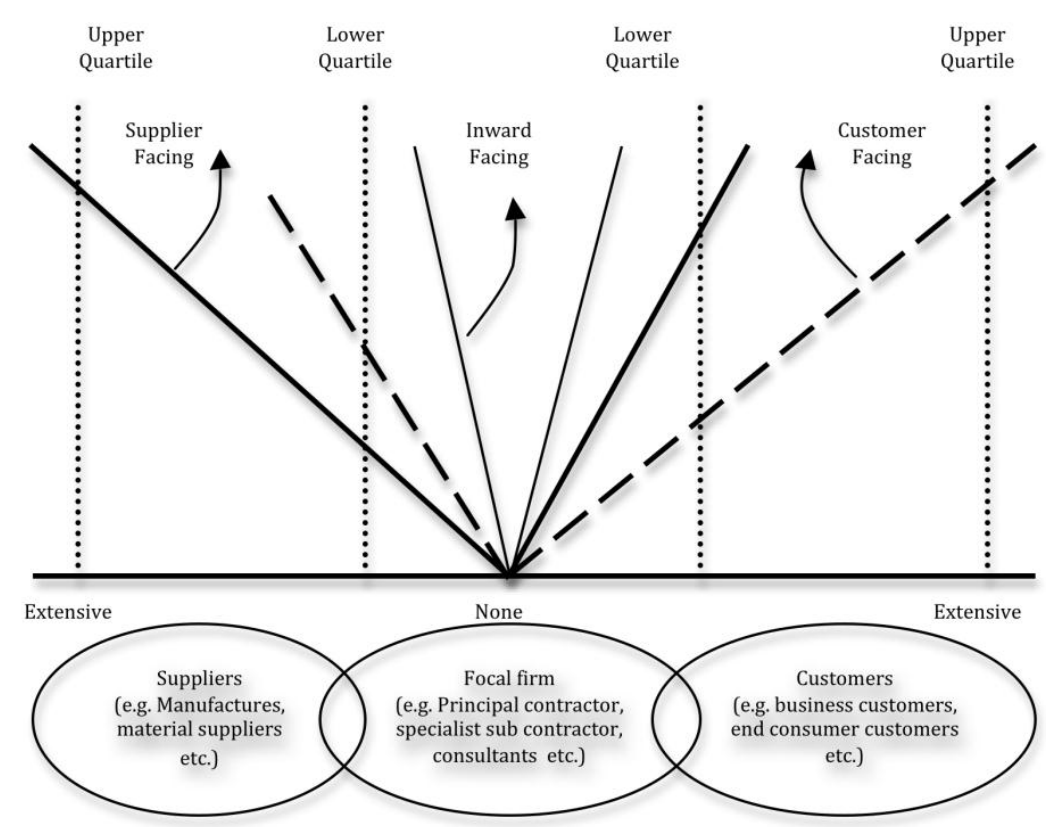

Figure 1 Arcs of integration modified from Frohlich and Westbrook (2001)

Gajendran, T et al. (2013) 'Internationalisation of construction business and e-commerce: Innovation, integration and dynamic capabilities', Australasian Journal of Construction Economics and Building, 13 (2) 1-17 
A firm's international business success partly depends on the extent innovation and integration is perpetuated by the members (suppliers and customers) and the functions (e.g. procurement, logistics, strategic planning etc.) of the supply chain. As indicated by Daniel and Wilson (2003), opportunities can arise from innovation in the culture, strategy, and management of ideas or organisation intelligence and/or from integration of information technology, strategy and supply chains. The extent of integration will depend on the contextual environment, including cultural, legislative, technical environments, within which the firms in the supply chain operate (Brisco and Dainty, 2005). Supply chain integration from a firm's perspective therefore, requires two modes of alignment: namely 'Information Integration' and 'Organisational Integration' (Bagchi and Skjoett-Larsen, 2003). Fawcett and Magnan (2002: 344) propose four types of integration, namely '(i) internal, cross-functional process integration; (ii) backward integration with valued first-tier suppliers leading to integration with second-tier; (iii) forward integration with valued firsttier customers; and (iv) complete forward and backward integration.' Extending the description of supply chain integration Frohlich and Westbrook (2001) identified five "arcs of integration" that describe the extent of integration across a supply chain using quartiles to position firms into one of the five categories (illustrated in Table 1 and Figure 1).

It is critical to note that the unique nature of the construction sector imposes additional layers of complexities, contributing to structural fragmentation, making supply chain integration more difficult in construction. The loosely coupled and transient nature of construction projects (Dubois and Gadde, 2002) manifests the construction project supply chains to be somewhat different to manufacturing supply chains. Each member of a project supply chain in construction e.g. consultant, project manager, contractor, sub contractors, suppliers and manufacturers, will be part of multiple transient supply chains concurrently. However, when firms develop long-term relationships leading to informal partnerships or consortia to deliver projects in a particular country and/or sector (e.g. project home, specialist healthcare, mining infrastructure etc.), such consortium's supply chains become relatively stable and less transient. This suggests that integration of a construction firm's project supply chains is complicated and firms in a project may not have total control of the entire project supply chain.

Consequently, individual firms need to develop dynamic capabilities to skilfully draw meaningful boundaries in their supply chains and create spheres within which they can foster and manage innovative initiatives, building up to sizeable competitive advantage. That is, each firm needs to skilfully strategise their supply chain integration at firm level and also on a project-by-project basis. As an example, a construction firm may have an overall strategy for a periphery facing supply chain, but in some projects they may choose backward integration while in other projects they may opt for forwarded integration as illustrated in Table 1 and Figure 1. Supply chain strategies can also be based on other perspectives, such as supply chain paradigms as outlined by Ayers (2002). He identified a number of paradigms including 'procurement, 'logistics and transportation', 'information' and 'strategic' as conceptualising supply chain operations. The paradigms are discussed below as contextualised in Daniel and Wilson's (2003) capability perspectives:

- The 'procurement paradigm' (PP) focuses on the procurement process across the supply chains and associate suppliers. The primary focus is improving the cost effectiveness of procurement process generally associated to the upstream supplier base. Sensing and seizing innovation and integration, the procurement approaches, specifically in the upstream spear (backward integration), and reconfiguring resources can iron out ineffectiveness in product or service delivery.

Gajendran, T et al. (2013) 'Internationalisation of construction business and e-commerce: Innovation, integration and dynamic capabilities', Australasian Journal of Construction Economics and Building, 13 (2) 1-17 
- The 'logistics and transportation paradigm' (LP) is focused on physical movement of the products and services. This is a key paradigm for firms that manufacture and distribute products: that is, planning, implementing, controlling the efficient flow and storage of goods and services and related information from the point of origin to the point of consumption. Sensing and seizing innovation and integration in the transportation solutions is critical for effectiveness in product or service delivery. Both forward and backward integration in terms of logistics becomes appropriate, based on the nature of the business and the position of the firm in the construction project supply chain.

- The 'information paradigm' (IP) focuses on improving information flows within the company and across the supply chain. This is assisted by integrated information systems, enabling effective flow of information to help improve coordination and cost of mistakes occurring due to lack of timely or accurate information. From the construction industry perspective, sensing and seizing innovation and integration of information sharing, has significant impact on effectiveness of business operations. Therefore, outward facing (backward and forward) integration can be argued to be appropriate.

- The 'strategic paradigm' (SP) focuses on aligning the strategic goals to supply chain design and execution and has a long-term orientation. This has the view that innovation in vision and strategy is critical to improve the market share and profit while cost is secondary (Ayers 2002). Construction firms may focus on strategy integration among the firms within predetermined boundaries of a supply chain.

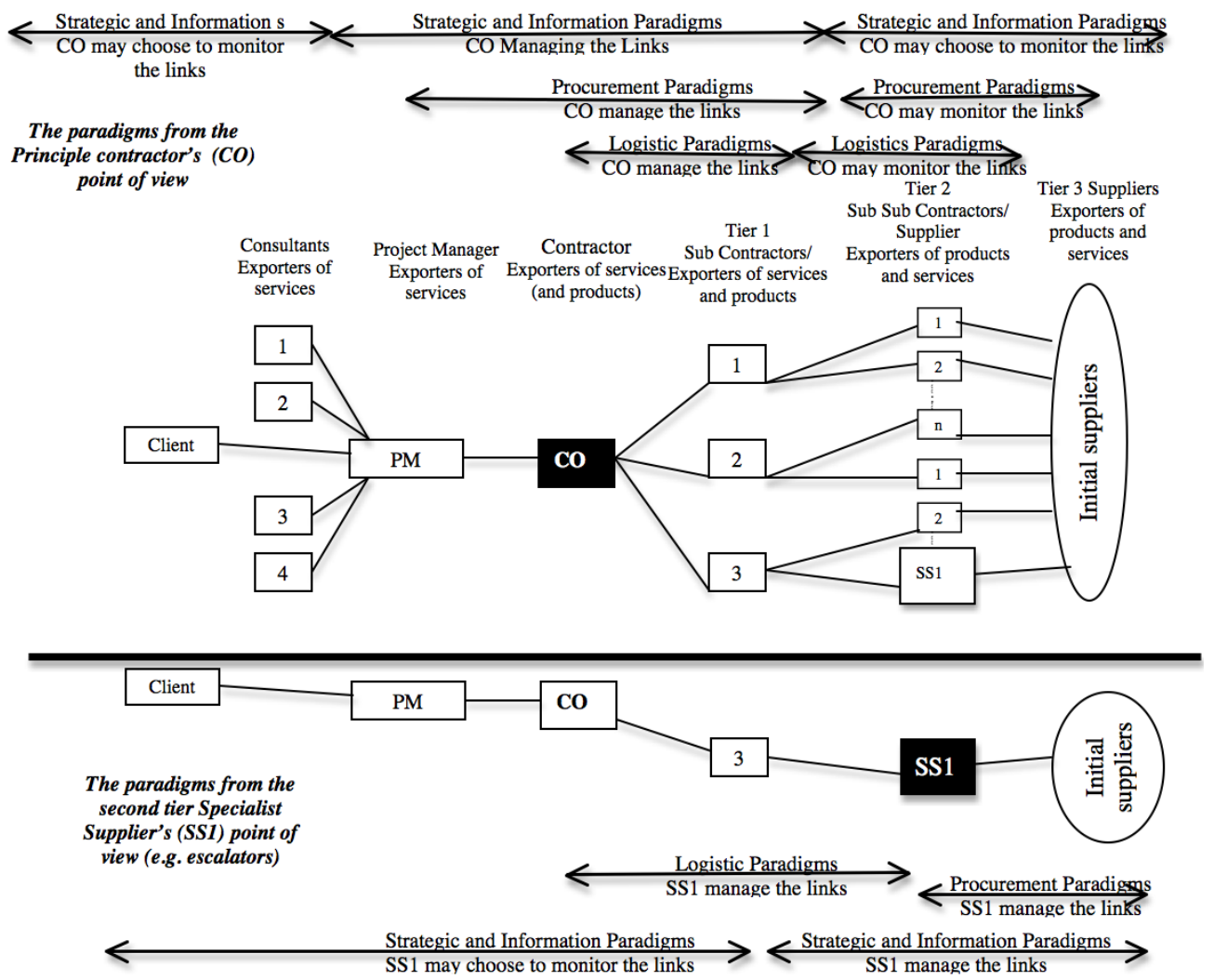

Figure 2 Supply paradigms from a contractor (top) and specialist supplier (bottom) perspectives

Gajendran, T et al. (2013) 'Internationalisation of construction business and e-commerce: Innovation, integration and dynamic capabilities', Australasian Journal of Construction Economics and Building, 13 (2) 1-17 
The above four paradigms are interconnected. Any successful supply chain design will encompass an appropriate mix of all the paradigms suitable in a selected business environment. Two examples on how to blend the different supply chain paradigms in a construction project context, focusing on a principal construction firm and a specialist supplier firm, are discussed below. Figure 2 presents a graphical representation of a construction project supply chain from the perspective 'principle contractor' and a 'specialist supplier' perspective (see Ash and Burn 2003 for a similar approach). Principal contractors roles in a project could differ based on the procurement method and contractual arrangement. The procurement or contractual differences along with other contextual factors, such as structure of the industry, transport and information infrastructure, in home and host countries, can influence the way each supply chain paradigm is exploited by a firm.

The supply chain in the top of Figure 2 identifies the dominant paradigms from a principal contractor's (CO) point of view hypothesised in a traditional procurement method, while the supply chain in the bottom focuses on a specialist supplier's (SS1) (e.g. escalator or lift firm) point of view. CO and SS1 can operate their upstream or suppliers' and downstream or customers' business activities in international markets. Hypothetically, an Australian contractor internationalising their construction business in Indonesia (either through export or FDI mode) essentially will need to appoint and manage a number of supply chain members including designers, sub contractors, suppliers etc. who have the possibility of operating from different geographical regions. For example, Leighton Asia, a subsidiary of Leighton Holdings (home country Australia), operating in Hong Kong, Macau, China, Mongolia, Taiwan, the Philippines, Thailand, Vietnam, Laos, Cambodia, Indonesia, Malaysia, Singapore and Brunei (Leighton, 2011) needs to manage their internationalised supply chains. As pointed out earlier, no firm including the $\mathrm{CO}$, has control of their entire supply chain. Therefore drawing boundaries within the supply chains to identify the spears of activities links CO's need to 'manage' and 'monitor' (refer to Figure 2) and is crucial for effectiveness (Lambert and Cooper, 2000). The CO can use e-commerce tools to manage and monitor their supply chain activities in the international markets.

The supply chain representation of the Specialist Supplier (SS1) shares mostly the characteristics of manufacturing supply chains (Ayers, 2002). For example, OTIS (elevator business that will fit the description of SS1 in Figure 2) is a global company with local roots in more than 200 countries and territories. It has revenue of US $\$ 11.7$ billion (in 2009), of which 80 percent was generated outside its home country (the United States). Their major manufacturing facilities are in the Americas, Europe and Asia and engineering facilities are in the United States, Austria, Brazil, China, Czech Republic, France, Germany, India, Italy, Japan, Korea and Spain (OTIS, 2010). OTIS appears to have a globalised and regionalised international business and provides e-services to its customers. SS1 supply chain can be more integrated and more permanent than construction project supply chains, which can be fragmented and temporary. Most of the specialist suppliers in the construction industry could source their suppliers from different countries and manufacture in cost effective geographical locations, marketing the products internationally. Based on the nature of the business and supply chain design, a variety of e-commerce tools can be adopted by businesses to be competitive.

In summary, the framework along with the arcs of integration, can provide the basis to analyse the dynamic capabilities that can emerge from blending the four supply chain paradigms proposed by Ayers (2002).

Gajendran, T et al. (2013) 'Internationalisation of construction business and e-commerce: Innovation, integration and dynamic capabilities', Australasian Journal of Construction Economics and Building, 13 (2) 1-17 


\section{Dynamic Capabilities and E-commerce}

E-commerce exploits the digital networks to conduct business transactions by way of sharing business information and maintaining business relationships (Zwass, 2003). Moreover, ecommerce digitally enables commercial transactions between and among trading parties which involves exchange of value (e.g. money) across organisational or individual boundaries in return for products or services (Laudon and Traver, 2009). E-commerce is "the delivery of information, products or services, or payments via telephone lines, computer networks or any other means" (Kalakota and Whinston, 1996, p. 3) and serves "as a medium for enabling end-to-end business transactions" (Kauffman and Walden, 2001, p. 3). In essence, e-commerce uses intent and computer networking capabilities to perform business activities i.e. buy, sell or exchange products, services, and information (Turban et al., 2010). The principle objectives of ecommerce applications are to improve the efficiency of current practices and/or support the development of new practices (Johnson et al., 2002). E-commerce models help conduct traditional commerce through new ways of transferring and processing information, therefore providing the base for firms to develop dynamic capabilities.

The technological innovations arising from the combination of telecommunication and organisational computing shifted the directions of e-commerce from I-commerce (Internet Commerce) to M-commerce (Mobile commerce) (Wu and Hisa, 2008; Swilley, Hofacker and Lamont, 2012). Swilley, Hofacker and Lamont (2012) found in their study that, due to the growing necessity to gain competitive advantage, firms are ready to leverage capabilities gained from e-commerce into m-commerce. Embracing the opportunities arising from the shifts in ecommerce environments requires managers to constantly reconfigure their business resourcescapabilities and meet emerging capability gaps in a timely manner (Zwass, 2003). Wu and Hisa (2008: 98) argue that e-commerce innovation can be attributed to a clever blend of technology with alternative business processes creating new forms of business models. A business model is a facilitating construct that blends the technologies and business values (Chesbrough and Rosenbloom, 2002) to provide structure to a business.

The application of e-commerce is not only about replacing paper trails or manual practices with digital alternatives but it implies more than that. E-commerce uses delicately interconnected electronic tools (e.g. computer networks, telephone, e-mail, electronic data interchange, internet, online collaborating tools and electronic funds transfer) to create a virtual network and virtual social space for trading partners or customers to communicate without requiring physical contact (Froehlich et al., 1999) making it attractive for international business. Corresponding to this, studies found that e-commerce can assist success of business internationalisation through relatively low cost business operations (Chai and Pavlou, 2004), enhancing the pace of business operations (Luo, Zhao and Du, 2005) and improving information and communication flow among all participants (Wang, Yang and Shen, 2007). E-commerce can reduce the cost of transactions for most businesses because it is easier to give the right offer to the right person at the right time, which in general, contributes to the efficiency of the business.

E-commerce can be classified into a number of modes including Business-to-Consumer (B2C), Business-to-Business (B2B) and Government to Business (G2B). Firms can engage with multiple e-commerce modes to form their international business. Major types of e-commerce are discussed below (Ash and Burn, 2003; Laudon and Traver, 2009; Turban et al., 2010; Dikbas and Scherer, 2004):

- Business-to-Consumer (B2C) e-commerce $\rightarrow$ online business selling to individual consumers. Most building supply firms directly reach the consumer. Moreover, the large

Gajendran, T et al. (2013) 'Internationalisation of construction business and e-commerce: Innovation, integration and dynamic capabilities', Australasian Journal of Construction Economics and Building, 13 (2) 1-17 
residential builders (e.g. project home firms) also can directly deal with their customers with $\mathrm{B} 2 \mathrm{C}$ tools.

- $\quad$ Business-to-Business (B2B) e-commerce $\rightarrow$ online business selling to other business. Most firms in a construction supply chain have the potential to engage with B2B systems. In general all suppliers and sub contractors can engage with the main contractor, project managers and beyond, making B2B a significant component of construction project business. Ash and Burn (2003) classifies B2B into a further two subsets $\mathrm{B}^{2} \mathrm{~B}^{\mathrm{s}}$ and $\mathrm{B}^{2} \mathrm{~B}^{\mathrm{C}}$, where the latter is about a business dealing with another business which is a corporate customer (e.g. a project home builder) who then passes the products or services to end-customer (e.g. a house buyer).

- E-Government e-commerce $\rightarrow$ is when a government entity buys or sells goods, services or information from or to, a business (G2B). G2B in the context of the construction sector involves use of online e-government platforms to engage with construction approvals, payment etc. This reduces cost of transactions for firms, particularly the ones that are geographically distanced from government offices.

- Business-to-Employees (B2E) $\rightarrow$ subset of intra-business category in which the organisation delivers services, information, or products to individual employees. Large construction companies offer products and services to their employees via online platforms, e.g. gym memberships, training programs and payroll management etc.

In summary, it is proposed that sensing and seizing alternative e-commerce modes and reconfiguring organisational resources (i.e. dynamic capability framework) offers the opportunity in the design of the project supply chain enabling construction firms to develop competitive advantages (Shera and Lee, 2004). Fusing the four supply chain paradigms proposed by Ayers (2002) and innovative and integrative capabilities proposed by Daniel and Wilson (2003) within the dynamic capability framework enables a further level of meaningful organisational analysis.

\section{Dynamic Capabilities embedded through the Coupling of Supply Chain and E- commerce Models}

As indicated previously, firms that produce and sell their products and services with e-enabled supply chains via effective flow of material, plant, people, finances and information will position the firm with a significant competitive position (Lambert and Cooper, 2000). Specifically, from a construction industry point of view, the effective management of information is a key factor in improving quality, cost efficiency and shortened project delivery times. In information intense environments the implementation of a coherent supply strategy embedded in e-commerce is vital for competitive advantage (Dikbas and Scherer, 2004). Eight unique features of ecommerce technology identified by Laudon and Traver (2009) (see Table 2) reinforce the potential of the e-commerce technology to develop dynamic capabilities to assist construction firms to create competitive advantage in their international business. It is evident that the features of e-commerce, such as ubiquity, global reach and interactivity, assists in improving the supply chain operations of any business (Zhu and Kraemer, 2002; Lee, 2001; Swilley, Hofacker and Lamont, 2012), including international business. E-commerce can be embedded into all four-supply chain paradigms.

Figure 3 provides a graphical representation of e-commerce concepts applied to construction supply chains. Although Figure 3 is focused on depicting a contractor's supply chain, the ecommerce embedded supply chain framework can be used to analyse other firms. Firms in the supply chain can be from various countries operating in export mode or FDI mode. Each firm in a project based on a firm's core business and nature of inbound or outbound operations, will have a distinct supply network. This will impact on the dominant supply chain paradigm(s) and

Gajendran, T et al. (2013) 'Internationalisation of construction business and e-commerce: Innovation, integration and dynamic capabilities', Australasian Journal of Construction Economics and Building, 13 (2) 1-17 
e-commerce tools aiding such paradigms. Supply chain connections in construction projects are underpinned by complex relationships that vary based on the procurement method, making it difficult to generalise atypical e-commerce approaches to internationalising the construction businesses. However, firms in the construction sector tend to be agile enough to cope with varying project supply chain needs. Table 2 identifies the key concepts that assist to align supply chain design to e-commerce tools.

\begin{tabular}{|c|c|}
\hline $\begin{array}{l}\text { E-commerce features } \\
\text { (Laudon and Traver, 2009) }\end{array}$ & $\begin{array}{l}\text { Construction internationalisation focus } \\
\text { (Ayers, 2002) }\end{array}$ \\
\hline $\begin{array}{l}\text { Ubiquity - e-commerce technology is } \\
\text { available everywhere (at home, at work, } \\
\text { via mobile) at anytime (servicing } 24 \mathrm{~h} \text { a } \\
\text { day, } 7 \text { days a week). }\end{array}$ & $\begin{array}{l}\text { Ubiquity is critical for 'information } \\
\text { paradigm'. This can allow firms located in } \\
\text { home and host countries to work in different } \\
\text { international time zones. }\end{array}$ \\
\hline $\begin{array}{l}\text { Global reach - the technology reaches } \\
\text { across national boundaries around the } \\
\text { world. }\end{array}$ & $\begin{array}{l}\text { The global reach and universal standards } \\
\text { of e-commerce can contribute to } \\
\text { 'information and strategic' paradigms by }\end{array}$ \\
\hline $\begin{array}{l}\text { Universal standards - create one set of } \\
\text { technology standards (internet based) } \\
\text { that is common, inexpensive, global } \\
\text { technology foundation for business use. }\end{array}$ & $\begin{array}{l}\text { technology for effective information flow at } \\
\text { strategic and operational levels. }\end{array}$ \\
\hline $\begin{array}{l}\text { Interactivity - the technology works } \\
\text { through interaction with the user. } \\
\text { Consumers/suppliers are engaged in } \\
\text { dialogues that dynamically adjust the } \\
\text { experience to the specific requirements. }\end{array}$ & $\begin{array}{l}\text { Interactivity can assist with 'procurement' } \\
\text { paradigm by developing relationships with } \\
\text { suppliers and reducing supply costs by } \\
\text { sharing accurate information. }\end{array}$ \\
\hline $\begin{array}{l}\text { Richness - video, audio, text message } \\
\text { are integrated into single message. }\end{array}$ & The rich, personalised and social nature of \\
\hline $\begin{array}{l}\text { Personalisation/Customisation - the } \\
\text { technology allows personalised } \\
\text { messages to be delivered based on } \\
\text { individual or group characteristics. }\end{array}$ & $\begin{array}{l}\text { ribute to the 'strategic' paradigm, by } \\
\text { of enabling firms to develop } \\
\text { ionships between suppliers and } \\
\text { umers, in home and host countries, to }\end{array}$ \\
\hline $\begin{array}{l}\text { Social technology - the technology } \\
\text { enables user content creation and } \\
\text { distribution and supports social networks. }\end{array}$ & \\
\hline $\begin{array}{l}\text { Information density - the technology } \\
\text { reduces information costs and raises } \\
\text { quality. Information becomes plentiful, } \\
\text { cheap and accurate. }\end{array}$ & $\begin{array}{l}\text { Ability to deal with high information density } \\
\text { can assist with 'logistic' and 'information' } \\
\text { paradigms by providing accurate } \\
\text { information during design and construction } \\
\text { stages. }\end{array}$ \\
\hline
\end{tabular}

Table 2 E-commerce features and focus for internationalisation of construction business

Figure 3 (drawn using concepts borrowed from Lambert and Cooper 2000, Ayers 2002 and) proposes potential opportunities that could be sensed and seized that from fusing the supply chain concepts and electronic commerce concepts outlined by Lambert and Cooper (2000), Ayers (2002) and Ash and Burn (2003). This figure illustrates how principal contractors can use B2B platforms to manage the operations with tier 1 sub contractors and project managers. Firms can also use B2B platforms to assist in monitoring the operations of tier 2 firms and upstream members of the supply chains (e.g. consultants) with appropriate security permissions). Moreover, the contractors can use B2C platform to improve customer relationship

Gajendran, T et al. (2013) 'Internationalisation of construction business and e-commerce: Innovation, integration and dynamic capabilities', Australasian Journal of Construction Economics and Building, 13 (2) 1-17 
management. Some of these operations can also be classified under $B 2 \mathrm{~B}^{\mathrm{c}}$. Although the engagement with $\mathrm{G} 2 \mathrm{~B}$ is driven by the government initiatives, firms exploiting the G2B opportunities can assist them with improving efficiencies.

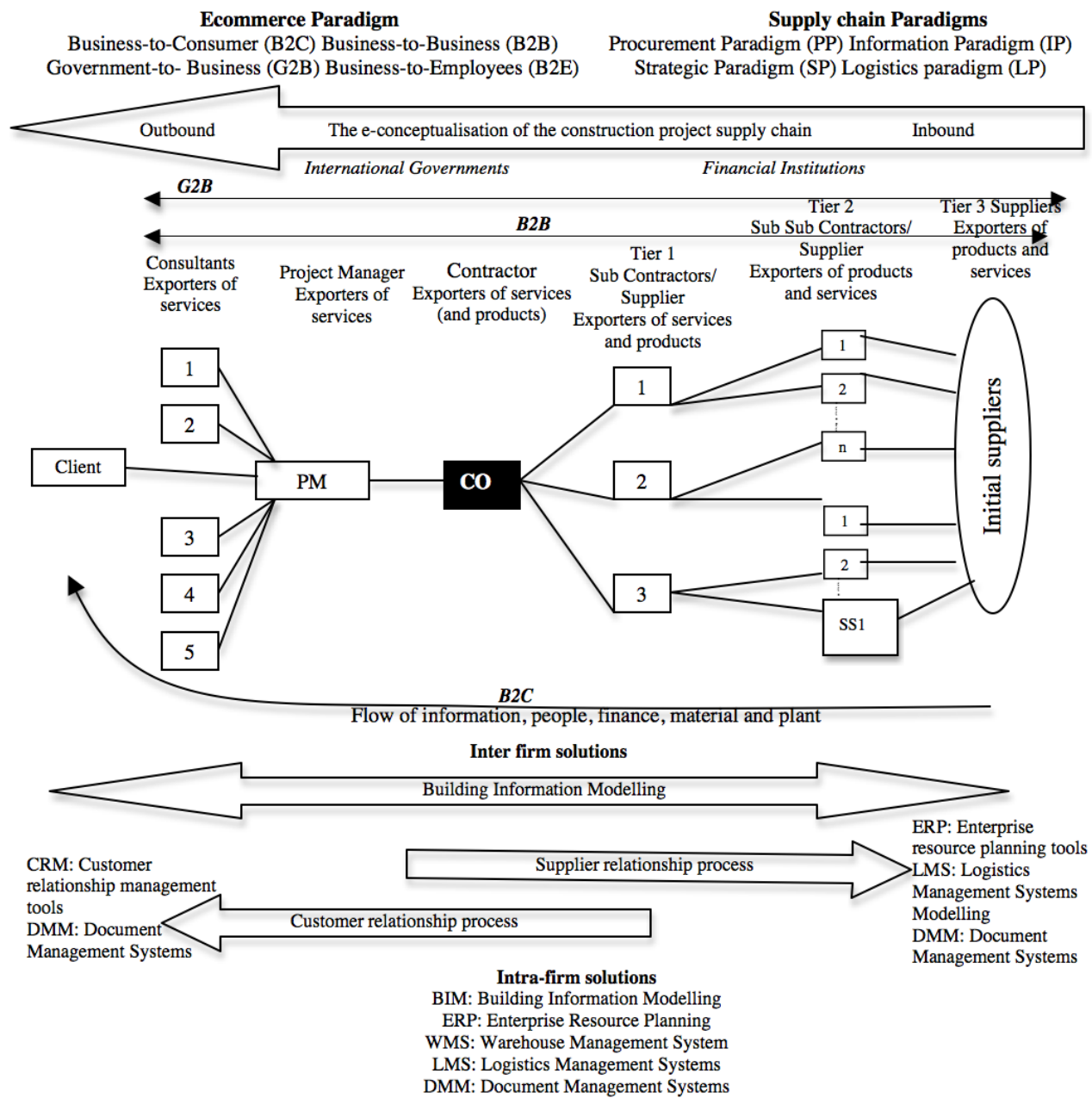

Figure 3 E-commerce in construction supply chains

(conceptualised from Lambert and Cooper 2000, Ayers 2002 and Ash and Burn, 2003)

Table 3 (constructed from concepts borrowed from, Ayers 2002 and Ash and Burn, 2003) proposes various broad categories of information technology systems that can assist to integrate different e-commerce initiatives aligned to supply chain-based initiatives (Issa, Flood and Caglasin, 2003). From a construction firm's point of view, G2B platforms will include any egovernment platform set to deal with approval-related issues of construction projects. G2B may assist with information and procurement paradigms. The Customer Relationship Management Systems will be central for B2C initiatives, assisting with information and strategic paradigms. The $\mathrm{B} 2 \mathrm{~B}$ platforms can be focused on specific activities relating to the business. They can include Online Document Management (Alshawi and Ingirige, 2003), Enterprise Resource Planning Systems (Akkermans et al., 2003; Su and Yang, 2010), and Warehouse or Logistics Management Systems (Voordijk, Leuven and Lann, 2003). These systems can assist with all four paradigms from inter and intra firm perspectives. The Building Information Modelling (BIM) 
technology has the potential to impact on the information, strategic and procurement paradigms (McGraw Hill Construction 2009, 2010; 2012).

\begin{tabular}{|c|c|c|}
\hline Paradigms & $\begin{array}{l}\text { Type of E- } \\
\text { commerce }\end{array}$ & $\begin{array}{c}\text { IT/E-commerce Tools (Inter and Intra firm } \\
\text { platforms) }\end{array}$ \\
\hline $\begin{array}{l}\text { Information } \\
\text { Paradigm } \\
\text { Strategic Paradigm } \\
\text { Procurement } \\
\text { Paradigm } \\
\text { Logistics Paradigm }\end{array}$ & $\begin{array}{l}\text { G2B } \\
\text { B2C } \\
\text { B2B }\end{array}$ & $\begin{array}{r}\text { e-Government portals (Inter) } \\
\text { Customer Relationship Management Systems (Inter) } \\
\text { Building Information Modelling (Inter \& Intra) } \\
\text { Online Document Management (Inter \& Intra) } \\
\text { Enterprise Resource Planning Systems (Inter \& Intra) } \\
\text { Warehouse Management Systems (Inter \& Intra) } \\
\text { Logistics Management Systems (Inter \& Intra) }\end{array}$ \\
\hline
\end{tabular}

Table 3 E-commerce in construction internationalisation of construction business

Primarily, contracting firms can exploit international markets by sensing and seizing opportunities offered by the e-commerce platform and reconfigure the firms' resources to (a) outsource business functions or operations to an international destination (upstream activities) and/or (b) offer the firm's products or services in the international market (downstream activities). The successful usage of e-commerce to support internationalisation is not without challenges. The asymmetry in e-commerce distribution seems to be caused not only by various levels of economic and socio-technical infrastructure, political and legal factors but also by cultural aspects in adopting e-commerce across nations. These have been recognised as major issues in the internationalisation of e-commerce (Kshetri, 2001). E-commerce can only be utilised competently at an optimum level if the employees and all clients have good ability to make use of the technology (Johnson and Whang, 2002). Thus, e-commerce platform for international business activities can be explored through dynamic capability routines exploiting innovation/integration capabilities.

\section{Concluding Remarks}

The construction firms can internationalise their business through import or export or FDI mode using an agile supply chain embedded with e-commerce capabilities. Exploiting international markets can occur in at least two forms: (a) outsource their selected business functions or operations to an international operator (supplier focus) and/or (b) offer the firm's products or services in the international market (customer focus). E-commerce allows firms, regardless of their size, type of business and geographical location to internationalise business in both FDI and import or export mode focusing on suppliers or customers.

In this paper it is proposed that fusing dynamic capability routines, namely sensing, seizing and re configuring proposed by Theece (2007) and 'Innovation' and 'Integration capabilities' proposed by Daniel and Wilson (2003) can provide an interesting analytical lens to explore adoption of emerging alterative ecommerce platforms in the context of a firms supply chain to gain competitive advantage. Dynamic capability framework enable on going sensing of (innovation and integration) opportunities, seizing the appropriate ones and re configuring resources to develop new business processes, products or models providing competitive advantage.

The paper specifically explored dynamic capability framework to analyse opportunities arising from innovation (in the culture, strategy, and management of ideas or organisation intelligence) and/or from integration (of information technology, strategy and supply chain) perpetuated by the members (suppliers and customers) in the functions (e.g. procurement, logistics, strategic

Gajendran, T et al. (2013) 'Internationalisation of construction business and e-commerce: Innovation, integration and dynamic capabilities', Australasian Journal of Construction Economics and Building, 13 (2) 1-17 
planning etc.) of the supply chain. The discourse indicates that innovation in all forms assists supply chain integration namely; (i) internal, cross-functional process integration; (ii) backward integration with valued first-tier suppliers, leading to integration with second-tier; (iii) forward integration with valued first-tier customers; and (iv) complete forward and backward integration, is strongly coupled with ICT (electronic) platforms and tools.

In essence this paper proposes a framework to conceptualise internationalisation of construction business through conscious sensing and seizing e-commerce opportunities in the context of their supply chain and reconfiguring the firms' resources. Based on the dominant supply chain paradigm (strategic, information, procurement, logistics) underlying the firm's business model, firms can choose their e-commerce approach (B2B, B2C etc) and tools (CRM, ERP BIM etc). Firms also need to be conscious of the need for both effective inter-company wide systems and intra-company or supply chain wide systems. It proposes that dynamic capabilities enable firms to exploit e-commerce platforms to channel upstream activities to an international destination and explore the opportunities to offer products and services to the international market.

\section{References}

Akkermans, H. A. Bogerd, P. Yucesan, E. and van Wassenhove, L. N. (2003) The impact of ERP on supply chain management: Exploratory findings from a European Delphi study, European Journal of Operational Research, 146, 284-301

Alshawi, M. and Ingirige, B. (2003) Web-enabled project management: an emerging paradigm in construction, Automation in Construction, 12, 349-364

Ambrosini, V and Bowman, C (2009) What are dynamic capabilities and are they a useful construct in strategic management? International Journal of Management Reviews, 11 (1), 2949

Ash, C. G. and Burn, J. M. (2003) Assessing the benefits from e-business transformation through effective enterprise management. European Journal of Information Systems, 12, pp. 297-308.

Ayers, J. B., Ed. (2002) Making Supply Chain Management Work, Auerbach Florida

Bagchi, P. K. and Skjoett-Larsen, T. (2003) Integration of Information technology and organisations in a supply chain, The International Journal of Logistics Management, 14 (1), 89108

Barreto, I, (2010) Dynamic Capabilities: A Review of Past Research and an Agenda for the Future, Journal of Management, 36 (1), 256-280

Briscoe, G. and Dainty, A. (2005) Construction supply chain integration: an elusive goal? Supply Chain Management, 10 (4), 319-325

Chai, L. and Pavlou, P. (2004) From 'ancient' to 'modern': a cross-cultural investigation of in electronic commerce adoption in Greece, Journal of Enterprise Information Management, 17 (6), 416-23

Chesbrough, H. and R. S. Rosenbloom (2002) The role of the business model in capturing value from innovation: Evidence from Xerox Corporation's technology spin-off companies, Industrial and Corporate Change, 11 (3), 529-555

Cutting-Decelle, A-F., Young, B. I., Das, B. P., Case, K., Rahimifard, S., Anumba, C. J. and Bouchlaghem, D. M. (2007) A review of approaches to supply chain communications: from manufacturing to construction, ITcon, 12 (2007), 73-102

Daniel, E. M. and Wilson, H. N. (2003) The role of dynamic capabilities in e-business

Gajendran, T et al. (2013) 'Internationalisation of construction business and e-commerce: Innovation, integration and dynamic capabilities', Australasian Journal of Construction Economics and Building, 13 (2) 1-17 
transformation, European Journal of Information Systems, 12, 282-296

Dikbas, A. and Scherer, R., Eds. (2004) eWork and eBusiness in Architecture Engineering and Construction ECPPM, Taylor \& Francis, London.

Donk, D. P. v. (2008) Challenges in relating supply chain management and information and communication technology: An introduction, International Journal of operations \& production management, 28 (4), 308-312

Dubois, A. and Gadde, L.-E. (2002) The construction industry as a loosely coupled system: implications for productivity and innovation, Construction Management and Economics, 20 (7), 621-631

Eisenhardt, K. M. and Martin, J. A. (2000) Dynamic capabilities: What are they? Strategic Management Journal, 21 (10/11), 1105-1121

Eyob, E. and Tetteh, G. (2012) Customer-Oriented Global Supply Chains: Concepts for Effective Management, (pp. 0-335), IGI Global, Web. 22 Mar. 2012. doi:10.4018/978-1-46660246-5

Fawcett, S. E. and Magnan, G. M. (2002) The rhetoric and reality of supply chain integration, International Journal of Physical Distribution and Logistics Management, 35 (5), pp. 339-361

Fawcett, S. E. Osterhaus, P. Magnan, G. M. Brau, J. C. and McCarter, M. W. (2007) Information sharing and supply chain performance: the role of connectivity and willingness, Supply Chain Management: An international Journal, 12 (5), 358-368

Froehlich, G., Hoover, H.J., Liew, W. and Sorenson, P.G. (1999) Application framework issues when evolving business applications for electronic commerce, Information Systems, 24 (6), 457473

Frohlich, M. T. and Westbrook, R. (2001) Arcs of integration: an internal study of supply chain strategies, Journal of Operations Management, 19, 185-200

Howes, R. and Tah, J. H. M. (2003) Strategic Management Applied to International Construction, Thomas Telford, Victoria

Issa, R. R. Flood, I. and Caglasin, G. (2003) A survey of e-business implementation in the US construction industry, ITcon, 8, 15-28

Johnson, E and Whang, S (2002) E-business and supply chain management: An overview and framework, Production and Operations Management, 11 (4), 413-23

Johnson, R., Clayton, M., Xia, G., Woo, J.H. and Song, Y. (2002) The strategic implications of e-commerce for the design and construction industry, Engineering Construction and Architectural Management, 9 (3), 241-248

Kalakota, R. and Whinston, A.B (1996) Frontiers of electronic commerce, Addison Wesley Longman Publishing Co., Inc. Redwood City, CA, USA

Kauffman, R.J. and Walden, E.A. (2001) Economics and electronic commerce: Survey and directions for research, International Journal of Electronic Commerce, 5, 5-116

Kshetri, N.B. (2001) Determinants of the locus of global e-commerce, Electronic Markets, 11 (4), 250-257

Lambert, D. M. and Cooper, M. C. (2000) Issues in Supply Chain Management, Industrial Marketing Management, 69 (1), 65-83

Laudon, K C. and Traver, C. G. (2009) E-Commerce: Business, Technology, and Society, 2nd. Ed., Addison Wesley 
Lee, C-S (2001) An analytical framework for looking at e-commerce business models and strategies. Internet Research: Electronic Networks, Applications and Policy, 11 (4), 349-59

Leighton Group. (2011). "About us", at

http://www.leightonasia.com/v4/default.asp?lid=1\&sec=About+Us (accessed May, 2011)

London, K. (2008), Construction supply chain economics, Taylor \& Francis, London

London, K. (2010). Multi-market industrial organisational economic models for the internationalisation process by small and medium enterprise construction design service firms, Architectural Engineering and Design Management, 6 (2), 132-152

Luo, Y., Zhao, J.H. and Du, J. (2005) The internationalisation speed of e-commerce companies: an empirical analysis, International Marketing Review, 22 (6), 693-709

McGraw Hill Construction (2009) The business value of BIM: Getting building information modelling to the bottom line, In: Smart Market Report

McGraw Hill Construction (2010) The business value of BIM in Europe: Getting building information modelling to the bottom line the united kingdom, France and Germany. In: Smart Market Report

McGraw Hill Construction (2012) The business value of BIM for infrastructure: Addressing America's infrastructure challenges with collaboration and technology

Makadok, R. (2001) Toward a synthesis of the resource-based and dynamic-capability views of rent creation, Strategic Management Journal, 22 (5), 387- 401

Menipaz, E. and Menipaz, A. (2011) International Business, SAGE, London

Min, H. and Zhou, G. (2002) Supply chain modelling: past, present and future. Computers \& Industrial Engineering, 43, 231-249

Nelson, R R and Winter, S G (1982) An evolutionary theory of economics, Cambridge: Harvard University Press.

O'Reilly III, C A and Tushman, M L (2008) Ambidexterity as a dynamic capability: Resolving the innovator's dilemma, Research in Organizational Behavior, 28 (July), 185-206

OTIS. (2010). OTIS Worldwide, at http://www.otisworldwide.com/ (accessed May 2011, 2011)

Pant, S. Sethia, R. and Bhandarib, M. (2003) Making sense of the e-supply chain landscape: an implementation framework, International Journal of Information Management, 23 (3), 2001-221

Porter, M E (1980) Competitive strategy: Techniques for analyzing industries and competitors, New York: Free Press.

Porter, M.E. (1990) The Competitive Advantage of Nations, Free Press, New York

Reina, P. and Tulacz, G. J. (2010a) The top 200 international design firms, ENR, ENR, New York

Reina, P. and Tulacz, G. J. (2010b) The top 225 international contractors, ENR, ENR, New York Rindova, V. P. and Kotha, S. (2001) "Morphing": Competing through Dynamic Capabilities, Form, and Function, The Academy of Management Journal, 44 (6), 1263-1280

Roy, S. Sivakumar, K. and Wilkinson, I. F. (2004) Innovation Generation in Supply Chain Relationships: A Conceptual Model and Research Propositions, Journal of the Academy of Marketing Science, 32 (1), 61-79

Rugman, A. M. and Collinson, S. (2009) International Business. Prentice Hall, Sydney

Shera, P. J. and Lee, V. C. (2004) Information technology as a facilitator for enhancing dynamic capabilities through knowledge management, Information \& Management, 41, 933-945 
Siau, K. and Tian, Y. (2004) Supply chain integration: architecture and enabling technologies, The Journal of Computer Information Systems, 44 (3), 67-72

Su, Y. and Yang, C. (2010) A structural equation model for analyzing the impact of ERP on SCM. Expert Systems with Applications, 37, 456-496

Smart, A. (2008) eBusiness and supply chain integration, Journal of Enterprise Information Management, 21 (3), 227-246

Swilley, E., Hofacker, C. F., and Lamont, B.T (2012) The Evolution from E-Commerce to MCommerce: Pressures, Firm Capabilities and Competitive Advantage in Strategic Decision Making, The international Journal of e-Business Research, 8 (1), 1-16

Tan, K. C. (2001) A framework of supply chain management literature, European Journal of Purchasing and Supply Management, 7, 39-48

Teece, D. and Pisano, G. (1994) The Dynamic Capabilities of firms: An introduction, The International Institute for Applied Systems Analysis, Austria

Teece, D. J. (2007) Explicating dynamic capabilities: The nature and microfoundations of (sustainable) enterprise performance, Strategic Management Journal, 28, 1319-1350

Teece, D. J. Pisano, G. and Shuen, A. (1997) Dynamic capabilities and strategic management, Strategic Management Journal, 18 (7), 509-533

Turban, E, Lee, J K, King, D, Liang, T P and Turban, D (2010) Electronic commerce, 6th ed. New Jersy: Prentice Hall Press

Voordijk, H. Leuven, A. V. and Lann, A. (2003) Enterprise Resource Planning in a large construction firms: implementation analysis, Construction Management and Economics, 21, 511-521

Vrijhoef, R. and Koskela, L. (2000) The four roles of supply chain management in construction, European Journal of Purchasing \& Supply Management, 6 (2000), 169-178

Wang, Y., Yang, J. and Shen, Q. (2007) The application of electronic commerce and information integration in the construction, International Journal of Project Management, 25 (2), 158-163

Winter, S. G. (2003) Understanding dynamic capabilities. Strategic Management Journal, 24, 991-995

Wu, J. H. and Hisa, T. L. (2008) Developing E-Business Dynamic Capabilities: An Analysis Of E-Commerce Innovation From I-, M-, To U-Commerce, Journal of Organisational Computing and Electronic Commerce, 18, 95-111

Zhu, K and Kraemer, K L (2002) E-commerce metrics for net-enhanced organizations: Assessing the value of e-commerce to firm performance in the manufacturing sector, Information Systems Research, 13 (3), 275-95

Zwass, V. (1996) Electronic commerce: structures and issues, International Journal of Electronic Commerce, 1 (1), 3-23

Zwass, V. (2003) Electronic commerce and organisational innovation: aspects and opportunities, International Journal of Electronic Commerce, 7 (3), 7-37

\footnotetext{
' International design: building (US\$8,504.6 Million [M]), industrial/petroleum (US\$21,351.0M), manufacturing (US\$ $404.1 \mathrm{M})$, transportation (US\$8,985.5M), power (US\$4,469.6M), hazardous waste (US\$2,090.4M), water (US\$ 2,755.7M) and sewer/waste (US\$1,762.8M) (values are for the year 2010-Source Reina and Tulacz, 2010a).

ii International contracting: building (US\$ \$86.0 Billion [B]), industrial /petroleum (US\$112.0B), manufacturing (US\$ $\$ 3.8 \mathrm{~B}$ ), transportation (US\$ \$112.3B), power (US\$ 35.7B), hazardous waste (US\$ 0.8B), water (US\$11.2B), Telecommunication (US\$2.7B) and sewer/waste (US\$ 6.3B) (values are for the year 2010 - source, Reina and Tulacz, 2010b).
} 